\title{
Adapting cropping systems to future climate change scenario in three agro-climatic zones of Punjab, India
}

\author{
S.K. JALOTA and B.B. VASHISHT \\ Department of Soil Science, Punjab Agricultural University, Ludhiana-141004, Punjab \\ Corresponding author E-mail: bharatpau@pau.edu
}

\begin{abstract}
The present study focuses on (1) projections of future climate data (for the years of 2020, 2050 and 2080) from three general circulation models (HadCM3, CCCMA-CGCM2 and CSIRO-MK2) for two scenarios (A2 and B2) for three agro-climatic zones of the Indian Punjab (ii) assessment of climate change impact on productivity of maize-wheat cropping system in moist to dry sub-humid, rice-wheat in hot dry semiarid and cotton-wheat in hot arid zones and (iii) evaluation of shifting planting dates as an adaptation measure to sustain crop yields. The results indicate that in future the magnitude of climate change and variability would vary with agro-climatic zone, model and scenario. Maximum temperature, minimum temperature and rainfall would be higher in moist to dry sub-humid zone than hot arid. Simulations with cropping system model anticipated reduction in yields of all the three cropping systems for future years; however, cotton crop was more vulnerable than maize and rice. Delaying trans/planting of maize by 7 days in sub humid zone, rice by $7-15$ days in semi arid and cotton by 21 days in arid zone in future emerged as doable adaptation measure to minimize yield reduction in future
\end{abstract}

Key words: General circulation models, Agro-climatic zones, CropSyst model, crop yields, adaptation

Punjab is known as the grain bowl of India. Averaged over last 30 years (1980-81 to 2010-11), it has contributed $31 \%$ rice and $50 \%$ wheat to the central pool from its meager area, $1.5 \%$ of India. But with changing agricultural lands to built-up due to increased population, food production in future will be at risk. IPCC projects a rise of global surface temperature within range of $0.4-2.6^{\circ} \mathrm{C}$ in $2046-2065$ and $0.3-$ $4.8^{\circ} \mathrm{C}$ in 2081-2100 relative to the reference period of 1986 2005 (IPCC, 2014). Recently Jalota et al. (2014) from RCM model projected that the central Indian Punjab is likely to experience $2.2-2.8$ and $4.7-5.5^{\circ} \mathrm{C}$ rise in average temperatures; 159-354 and 181-561 mm more rainfall during mid century (2020-2050) and end century (2071-2098) century, respectively than the present time slice. This is going to have profound effect on crop productivity. To obtain stable production in required quantity, it is important to understand the impact of climate change and possible adaptation measures to tone down that impact in a given environment. For climate change scenario, daily weather data is mostly projected from general circulation models (GCM) and regional climate models ( $\mathrm{RCM})$. Although, there is considerable uncertainty about future, yet the changes in spatial and temporal pattern in climatic variables due to global warming and their impact on crop productivity have been studied in different parts of the world (Jalota et al.,
2014; Vashisht et al., 2013; Tubiello et al., 2000). Based on the hydrological and climatic conditions, Indian Punjab has three agro-climate zones viz. moist to dry sub-humid in north east, hot dry semiarid as central plains and hot typical arid in south west. The main cropping systems in the respective zones are maize-wheat $(\mathrm{M}-\mathrm{W})$, rice-wheat $(\mathrm{R}-\mathrm{W})$ and cotton-wheat $(\mathrm{C}-\mathrm{W})$. Presently at research farms, the average productivity of maize (Zea mays L.), rice (Oryza sativa L.), seed cotton (Gossypium hirsutum L.) and wheat (Triticum aestivum L.) is 4.0, 6.5, 2.0 and 5.6 $\mathrm{tha}^{-1}$, respectively. To sustain these yields in future, it is important to understand the impact of climate change on the productivity of three main cropping systems in their respective agro-climatic zones. The favorable effect of elevated $\mathrm{CO}_{2}$ and unfavorable effect of elevated temperature and their interactions on crop production from free air carbon dioxide enrichment experiments (FACE), open top chamber(OTC), temperature gradient tunnel (TGT) and crop modeling is well documented in the literature (Kimball et al., 2002; Jalota et al., 2013a; Jalota et al., 2013b; Kaur et al., 2012). Keeping this in view, the present study was undertaken with the objectives (i) projection of future climate data from three general circulation models (GCMs) for two scenarios for three agro-climatic zones of the Indian Punjab (ii) assessment of climate change impact on productivity of different cropping systems (iii) 
evaluation of shifting planting dates as an adaptation measure to sustain crop yields.

\section{MATERIALS AND METHODS}

\section{Sites and climate data}

Dailyweather data of 21 years (1989-2009) on maximum temperature $\left(\mathrm{T}_{\max }\right)$, minimum temperature $\left(\mathrm{T}_{\min }\right)$ and rainfall (RF) recorded at meteorological observatories at Ballowal $\left(30^{\circ} 41^{\prime}\right.$ to $32^{\circ} 30^{\prime} \mathrm{N}, 75^{\circ} 30^{\prime}$ to $\left.76^{\circ} 48^{\prime} \mathrm{E}\right)$, Ludhiana $\left(30^{\circ} 75^{\prime} \mathrm{N}\right.$, $\left.75^{\circ} 48^{\prime} \mathrm{E}\right)$ and Bathinda (30 $\left.58^{\prime} \mathrm{N}, 74^{\circ} 18^{\prime} \mathrm{E}\right)$ was collected. These meteorological observatories represents three agroclimatic zones viz. dry sub-humid (annual $\mathrm{T}_{\max } 29.7^{\circ} \mathrm{C}, \mathrm{T}_{\min }$ $16.1^{\circ} \mathrm{C}$ and RF $1122 \mathrm{~mm}$ ) in north east, hot dry semiarid (annual $\mathrm{T}_{\text {max }} 30.5^{\circ} \mathrm{C}, \mathrm{T}_{\min } 15.4^{\circ} \mathrm{C}$ and $\mathrm{RF} 714 \mathrm{~mm}$ ) in central part and hot typical arid (annual $\mathrm{T}_{\max } 31.5^{\circ} \mathrm{C}, \mathrm{T}_{\min } 16.9^{\circ} \mathrm{C}$ and RF $539 \mathrm{~mm}$ ) in south west of Indian Punjab. For these three locations, climate change was projected from three GCMs (HadCM3, CSIRO-Mk2 and CCCMACGCM2) for two scenarios one for economic development (A2) and the other for environmental development (B2) defined in the Special Report on Emissions Scenarios. Rationale for using these three GCMs over others was to obtain change in $\mathrm{T}_{\max }$ and $\mathrm{T}_{\text {min }}$ instead of average temperature, which was required as input in weather data to the cropping system simulation (CropSyst) model used in this study. Climate data for the years of 2020, 2050 and 2080 represents the averaged data of 30 years i.e. from 2010 to 2039, from 2040-2069 and 20702099, respectively. The change was against a baseline data, i.e., the average of 30 years of historical data (from 1961 to 1990). Daily weather data on Tmax, Tmin and RF was created through addition/ subtraction of the monthly change (assumed same change for each day in the respective month) to the daily observed data taken as baseline (IPCCTGICA, 2007) In the present study, the observed daily weather data for 21 years (1989-2009) of the study area was used as baseline.

\section{Crop simulation model}

Simulations for crop duration and yield were run using CropSyst model, which is a multiyear, multi crop, daily time-step cropping system simulation model (Stockle et al., 1994). In the model, the soil files were prepared from the observed field data of the three locations, representing agro-climatic zones (Table 1). The management file consisting of time and amount of irrigation and nitrogen fertilizer applied was developed for cropping systems as per package of practices by Punjab Agricultural University, Ludhiana (http://web.pau.edu/content/pf/pp). This model has already been intensively calibrated and validated for rice-wheat (Jalota et al., 2011), maize-wheat (Jalota et al., 2010) and cotton-wheat (Butter et al., 2012) cropping systems in their respective climatic zones.

By making use of daily weather data for 2020, 2050 and 2080 total crop duration and yield were simulated for all the three cropping systems with elevated $\mathrm{CO}_{2}(420 \mathrm{ppm}$ in 2020,480 ppm in 2050 and 540 ppm in 2080) levels as per Bern climate change model (www.ipcc-data.org/ancillary/tarbern.txi). Simulations were run for normal planting dates (NPD) i.e. June $20^{\text {th }}$ for rice (varietyPR 111 ), July $8^{\text {th }}$ for maize (variety JH 3459), May $1^{\text {st }}$ for cotton (variety LH1556). Wheat after maize and rice was planted on November $5^{\text {th }}$ and after cotton on December $1^{\text {st }}$ (variety PBW 343). For studying the effect of shifted dates simulation were started from NPD+7days, NPD+15days and NPD+21 days. Equivalent wheat yield was estimated as equation 3. Price of the crop was taken equal to minimum support price i.e. ' (Indian rupee) $9.80,11.10,28.00$ and $12.85 \mathrm{~kg}^{-1}$ for maize, rice, cotton and wheat, respectively (http://pbplanning.gov.in/pdf/ Statistical Abstract)

Equivalent wheat yield $=$ Yield of wheat $+($ Yield of the crop*Price of the crop/ Price of wheat) (3)

\section{RESULTS AND DISCUSSION}

\section{Projected future data}

The projected annual change in climate parameters $\left(\mathrm{T}_{\max }, \mathrm{T}_{\min }\right.$ and RF) under different agro-climatic zones, climate models and scenarios in years of 2020, 2050 and 2080 are presented in Table 2. In all the climate parameters, the change would be positive showing an increasing trend except the rainfall by CSIRO model, which was negative in B2 scenario of 2020 and in both the scenarios in 2050 and 2080 in semi arid and arid zones. Averaged over climate models and scenarios, the increase in $\mathrm{T}_{\max }, \mathrm{T}_{\min }$ and $\mathrm{RF}$ would be relatively more by $0.10,0.16$ and $16.2 \mathrm{~mm}$ in moist to dry sub-humid zone than hot arid. Averaged across agro climatic zones, climate models and scenario, $\mathrm{T}_{\max }$ would increase by $1.1,2.2$ and $3.6^{\circ} \mathrm{C} ; \mathrm{T}_{\min }$ by $1.7,3.0$ and $4.2^{\circ} \mathrm{C}$ and RF by 37.8, 49.2 and $57 \mathrm{~mm}$ in 2020, 2050 and 2080, respectively. Amongst the models, averaged increase in $\mathrm{T}_{\max }$ and $\mathrm{T}_{\text {min }}$ would be more by CSIRO model and RF by HadCM3. Averaged (across agro climatic zones and models) increase in $\mathrm{T}_{\text {max }}$ and $\mathrm{T}_{\text {min }}$ would be more under $\mathrm{A} 2$ scenario than B2 in years of 2050 and 2080 while in 2020 trend is in reverse order. Change in RF would be more under B2 scenario in 2080. The average variability, across agro climatic zones, 
Table 1: Soil profile characteristics representing three agro climatic zones

\begin{tabular}{|c|c|c|c|c|c|c|c|c|}
\hline $\begin{array}{l}\text { Soil } \\
\text { layers }\end{array}$ & $\begin{array}{c}\text { Soil } \\
\text { depth }(\mathrm{m})\end{array}$ & $\begin{array}{l}\text { Sand } \\
(\%)\end{array}$ & $\begin{array}{l}\text { Silt } \\
(\%)\end{array}$ & $\begin{array}{l}\text { Clay } \\
(\%)\end{array}$ & $\begin{array}{c}\text { Soil } \\
\text { moisture } \\
\left(\mathrm{m}^{3} \mathrm{~m}^{-3}\right)\end{array}$ & $\begin{array}{c}\mathrm{NO}_{3} \\
\left(\mathrm{~kg} \mathrm{ha}^{-1}\right)\end{array}$ & $\begin{array}{c}\mathrm{NH}_{4} \\
\left(\mathrm{~kg} \mathrm{ha}^{-1}\right)\end{array}$ & $\begin{array}{c}\text { Organic } \\
\text { matter }(\%)\end{array}$ \\
\hline \multicolumn{9}{|c|}{ Moist to dry sub humid } \\
\hline 1 & $0-0.15$ & 77.5 & 13.8 & 8.8 & 0.138 & 23.52 & 15.68 & 0.489 \\
\hline 2 & $0.15-0.30$ & 83.8 & 8.8 & 7.5 & 0.130 & 19.60 & 7.84 & 0.371 \\
\hline 3 & $0.30-0.45$ & 78.8 & 12.8 & 8.8 & 0.135 & 15.68 & 21.57 & 0.231 \\
\hline 4 & $0.45-0.60$ & 82.5 & 10.0 & 7.5 & 0.135 & 23.52 & 16.80 & 0.180 \\
\hline 5 & $0.60-0.75$ & 80.0 & 11.3 & 8.8 & 0.064 & 25.49 & 11.76 & 0.052 \\
\hline 6 & $0.75-0.90$ & 82.5 & 10.0 & 7.5 & 0.064 & 27.44 & 13.73 & 0.128 \\
\hline 7 & $0.90-1.05$ & 85.0 & 8.8 & 6.3 & 0.035 & 41.17 & 8.02 & 0.473 \\
\hline 8 & $1.05-1.20$ & 82.9 & 8.8 & 8.4 & 0.035 & 30.58 & 3.92 & 0.231 \\
\hline 9 & $1.20-1.35$ & 75.4 & 13.8 & 10.9 & 0.033 & 23.52 & 3.92 & 0.257 \\
\hline 10 & $1.35-1.50$ & 66.6 & 18.8 & 14.7 & 0.033 & 35.28 & 5.94 & 0.185 \\
\hline 11 & $1.50-1.65$ & 59.1 & 23.8 & 17.2 & 0.031 & 27.44 & 17.36 & 0.103 \\
\hline 12 & $1.65-1.80$ & 61.6 & 22.5 & 15.9 & 0.031 & 33.33 & 1.97 & 0.075 \\
\hline \multicolumn{9}{|c|}{ Hot dry semi-arid } \\
\hline 1 & $0-0.15$ & 59 & 7 & 34 & 0.40 & 10.53 & 7.84 & 0.707 \\
\hline 2 & $0.15-0.30$ & 68 & 4 & 28 & 0.40 & 18.37 & 7.84 & 0.638 \\
\hline 3 & $0.30-0.45$ & 56 & 8 & 36 & 0.30 & 10.53 & 5.15 & 0.603 \\
\hline 4 & $0.45-0.60$ & 55 & 13 & 32 & 0.30 & 20.83 & 15.68 & 0.569 \\
\hline 5 & $0.60-0.75$ & 54 & 20 & 26 & 0.30 & 20.83 & 12.99 & 0.379 \\
\hline 6 & $0.75-0.90$ & 56 & 9 & 35 & 0.30 & 26.21 & 2.69 & 0.259 \\
\hline 7 & $0.90-1.05$ & 55 & 10 & 35 & 0.30 & 15.68 & 5.15 & 0.241 \\
\hline 8 & $1.05-1.20$ & 59 & 8 & 33 & 0.30 & 18.37 & 5.15 & 0.190 \\
\hline 9 & $1.20-1.35$ & 59 & 16 & 25 & 0.30 & 26.21 & 2.69 & 0.155 \\
\hline 10 & $1.35-1.50$ & 68 & 8 & 24 & 0.30 & 23.52 & 7.84 & 0.138 \\
\hline 11 & $1.50-1.65$ & 74 & 5 & 21 & 0.30 & 26.21 & 5.15 & 0.103 \\
\hline 12 & $1.65-1.80$ & 75 & 2 & 23 & 0.3 & 2.69 & 7.84 & 0.069 \\
\hline \multicolumn{9}{|c|}{ Hot typic arid } \\
\hline 1 & $0-0.15$ & 80.0 & 12.5 & 7.5 & 0.200 & 23.52 & 17.65 & 0.724 \\
\hline 2 & $0.15-0.30$ & 92.5 & 5.0 & 2.5 & 0.200 & 31.36 & 11.76 & 0.543 \\
\hline 3 & $0.30-0.45$ & 81.3 & 10.0 & 8.8 & 0.180 & 29.41 & 7.84 & 0.207 \\
\hline 4 & $0.45-0.60$ & 72.5 & 17.5 & 10.0 & 0.160 & 39.20 & 15.68 & 0.258 \\
\hline 5 & $0.60-0.75$ & 72.5 & 17.5 & 10.0 & 0.140 & 27.44 & 5.89 & 0.181 \\
\hline 6 & $0.75-0.90$ & 68.8 & 20.0 & 11.3 & 0.120 & 27.44 & 3.92 & 0.155 \\
\hline 7 & $0.90-1.05$ & 72.5 & 17.5 & 10.0 & 0.100 & 31.36 & 15.68 & 0.698 \\
\hline 8 & $1.05-1.20$ & 70.4 & 17.5 & 12.2 & 0.080 & 43.12 & 7.84 & 0.414 \\
\hline 9 & $1.20-1.35$ & 71.6 & 18.8 & 9.7 & 0.050 & 47.04 & 11.76 & 0.362 \\
\hline 10 & $1.35-1.50$ & 69.1 & 20.0 & 10.9 & 0.050 & 31.36 & 3.92 & 0.362 \\
\hline 11 & $1.50-1.65$ & 51.6 & 31.3 & 17.2 & 0.050 & 35.28 & 0.20 & 0.259 \\
\hline 12 & $1.65-1.80$ & 37.9 & 42.5 & 19.7 & 0.050 & 45.09 & 0.20 & 0.129 \\
\hline
\end{tabular}




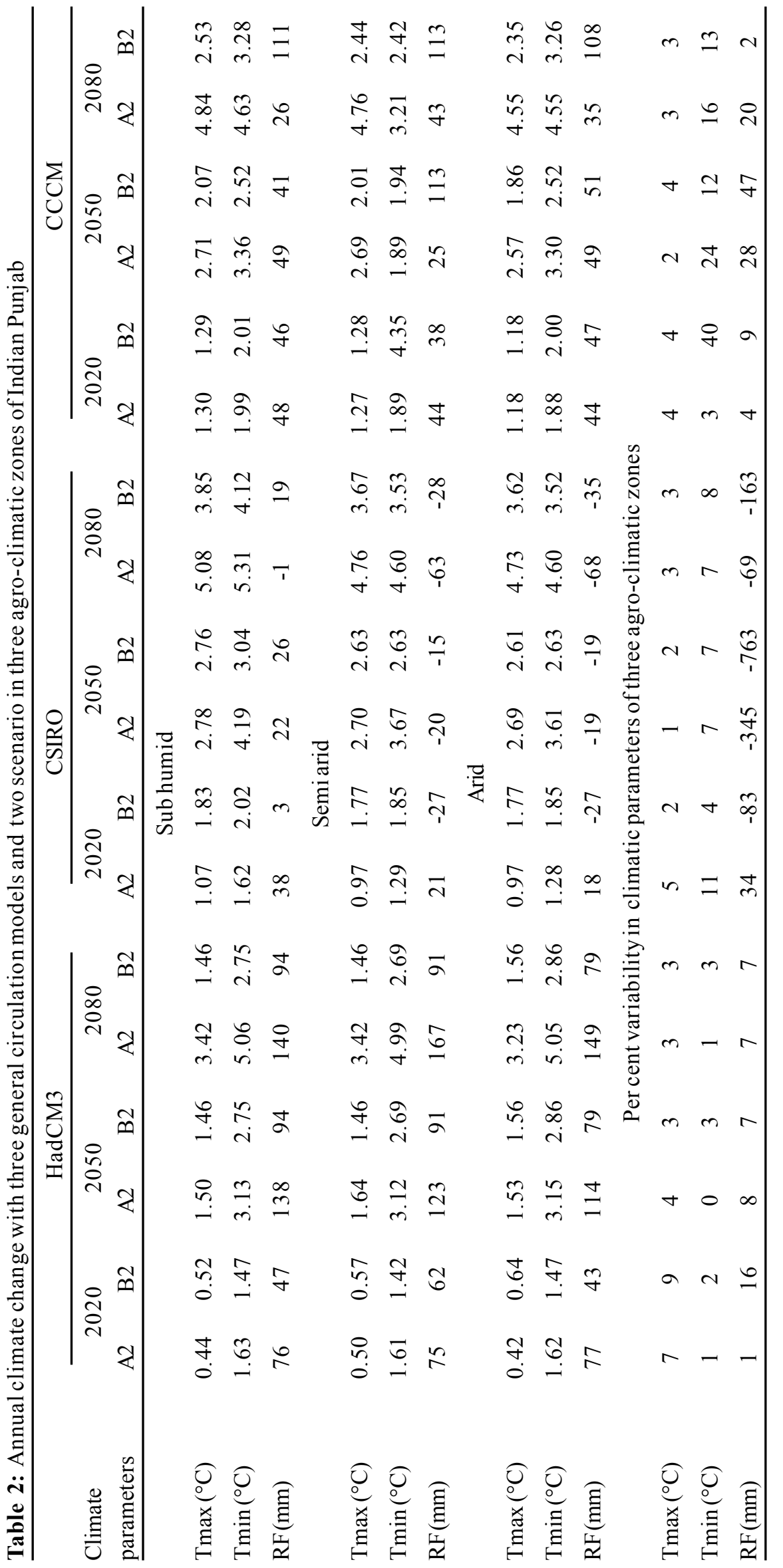




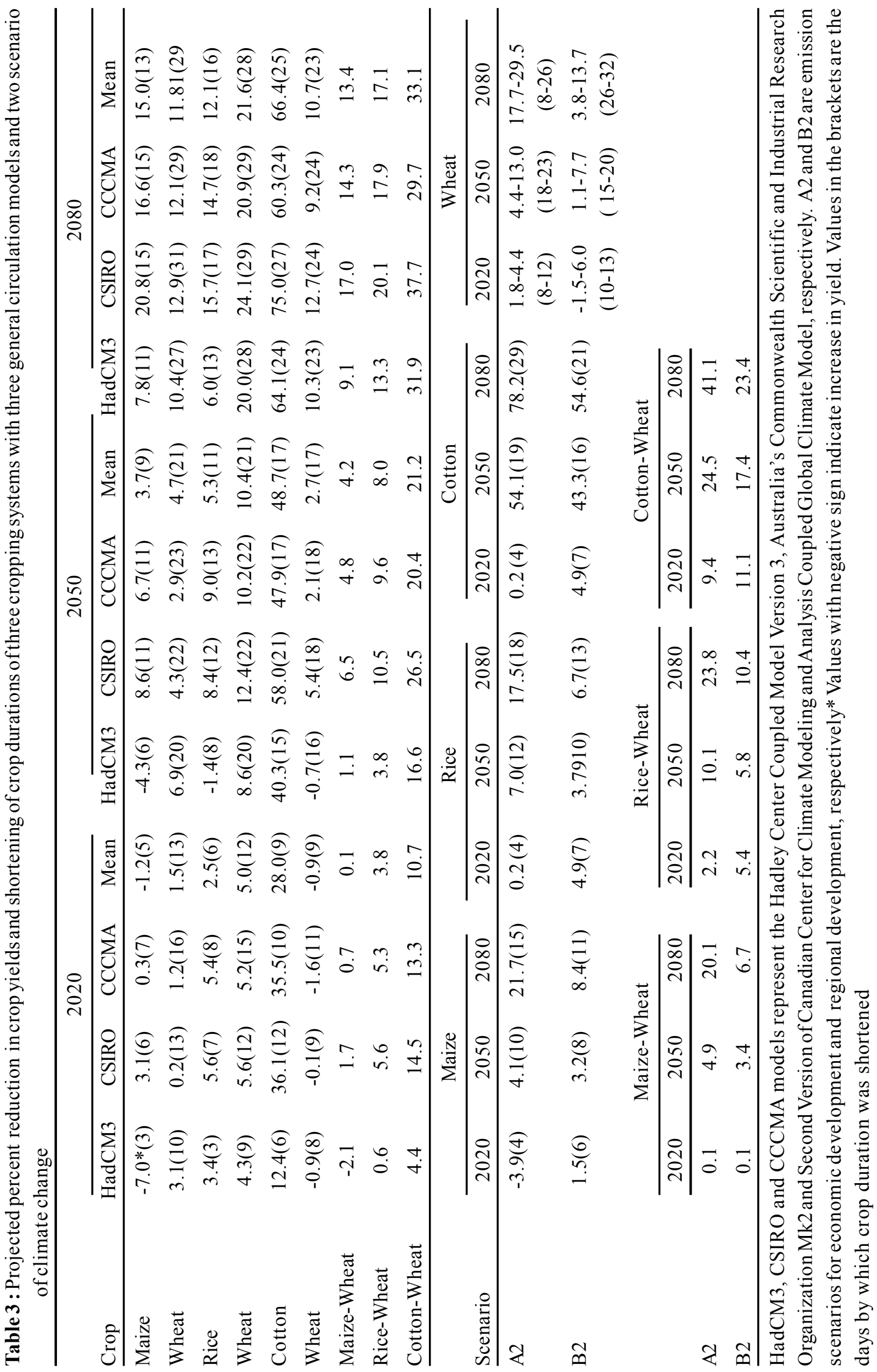




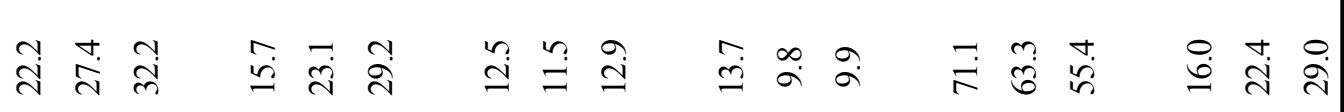

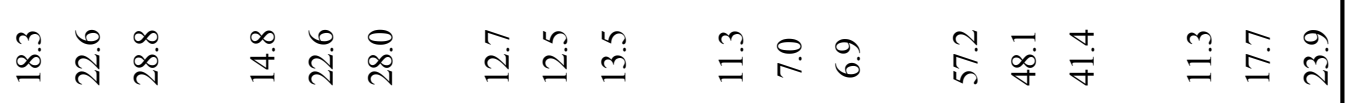

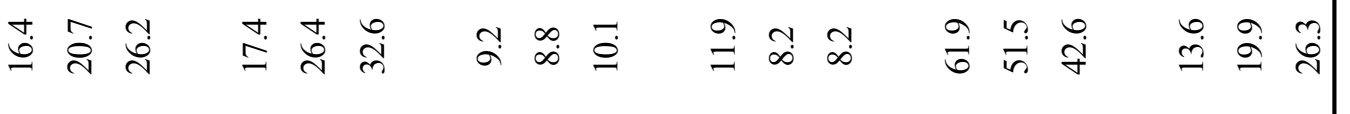

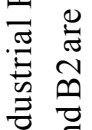

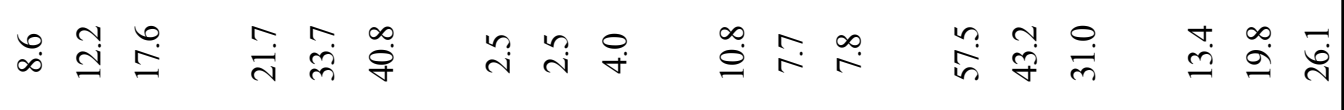

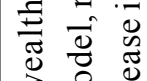

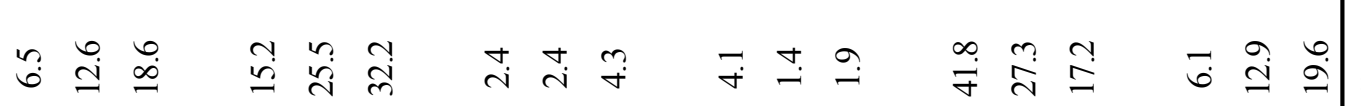
U $\overline{0}$

๙ֶ) 要

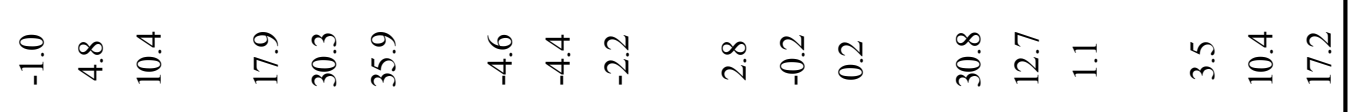

일

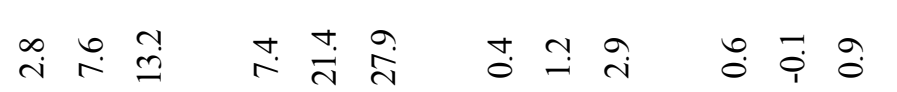

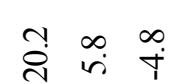

ते

$\circlearrowright \sum$

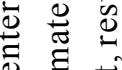

$\stackrel{\infty}{m}$

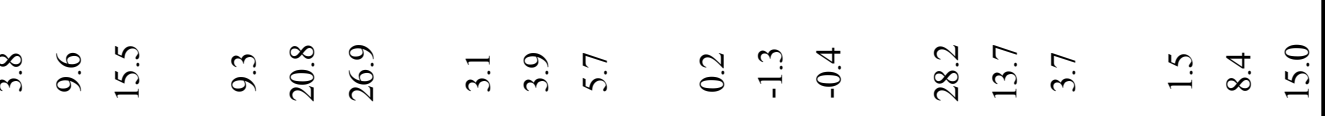
0

$\underset{r}{\stackrel{+}{r}} \stackrel{n}{r}$

$\because \stackrel{n}{0} \stackrel{0}{0}$

ก.

ㅇ. $\ln$

ஷे

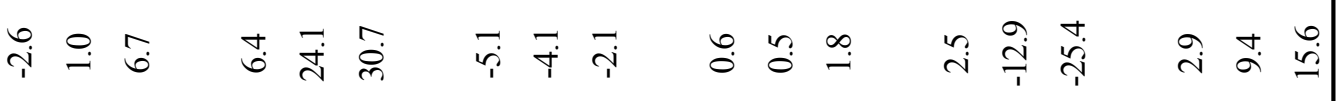


climate models and scenarios, in the years of 2020, 2050 and 2080 was 5,3 and $3 \%$ in $\mathrm{T}_{\max } ; 10,9$ and $8 \%$ in $\mathrm{T}_{\text {min }} ;-3,-170$ and $-33 \%$ in RF, respectively. Amongst the models, the highest variability (8\%) was in HADCM3 for $\mathrm{T}_{\text {max }}$; and $21 \%$ in CCCM3 for $\mathrm{T}_{\min }$ model in the year of 2020. For RF highest variability was $-554 \%$ in CSIRO in 2050. Similarly amongst scenarios, higher variability ( $5 \%$ ) was in $\mathrm{A} 2$ for $\mathrm{T}_{\max }$ and $15 \%$ in $\mathrm{B} 2$ for $\mathrm{T}_{\min }$ in 2020 . For RF, highest variability (-236\%) was in $\mathrm{B} 2$ in 2050. These projected climate parameters indicate that the magnitudes of increase and variability in these would vary with location of the agro climate zone, climate model and scenario. The magnitude of increase and variability would be more in $\mathrm{T}_{\text {min }}$ than that of $\mathrm{T}_{\max }$. In RF, variability would be more than temperature. The intraannual (monthly) change showed that $\mathrm{T}_{\max }$ would increase in the range from -0.1 to $1.7,0.8$ to 3.0 and 1.7 to $4.4^{\circ} \mathrm{C}$ in 2020 , 2050 and 2080, respectively. The corresponding increase in $\mathrm{T}_{\min }$ would be in the range of 0.9 to $2.6,2.4$ to 4.0 and 3.4 to $5.3{ }^{\circ} \mathrm{C}$, respectively. The range of increase in RF would be from -73 to $205,-62$ to 231 and -97 to $423 \mathrm{~mm}$ in 2020,2050 and 2080 , respectively. Amongst the different months in 2020, 2050 and 2080, the August would realize the negative change in $\mathrm{T}_{\max }$, lower in $\mathrm{T}_{\min }$ and higher in rainfall. The magnitude of increase in $\mathrm{T}_{\max }$ would be higher in the month of March in 2020, February in 2050 and 2080. The higher increase of $\mathrm{T}_{\min }$ would be in the month of January and of RF in the month of August in 2020, 2050 and 2080.

\section{Crop yields}

The per cent reduction in yields of three cropping systems in the years 2020, 2050 and 2080 are given in Table 3 . Averaged across climate models, reduction in yield of maize, rice and cotton crops at NPD would be -1.2, 2.5 and $28.0 \%$ in $2020,3.7,5.3$ and $48.7 \%$ in 2050 and $15.0,12.1$, and $66.4 \%$ in 2080 , respectively. In wheat range of yield reduction in different cropping systems would be from -0.9 to 5.0, 2.7 to 10.4 and 10.7 to $21.6 \%$ in 2020,2050 and 2080 , respectively. Relatively more reduction in cotton is due to the reason that that at high temperature cotton plants lose their reproductive capacity to a greater extent than their ability to produce biomass and face problem of cotton sterility and boll retention (Sankaranaryanan et al., 2010). The reduction in yield also corresponds to shortening of the crop duration with increased temperature. The crop duration (given in parentheses) in 2020, 2050 and 2080 would be shortened by 5,9 and 13 days in maize; 6,11 and 16 days in rice; 9, 17 and 25 days in cotton, respectively. The corresponding shortening in wheat would be 9-13, 17-21 and 23-29 days depending upon the preceding crop in the system. This data showed that shortening of crop duration was more in cotton than rice than maize and trend reversed in subsequent wheat i.e. least shortening of wheat duration following cotton. The yield reduction with shortening of crop duration under elevated temperature in this region are in line with the previous documented results obtained with hypothetical change in temperature or from GCMs and RCM climate data (Vashisht et al., 2013; Jalota et al., 2013a; Jalota et al., 2013b) and from field (Peng et al., 2004; Haris et al., 2011). Projections from different climate models and the scenarios also affected the crop yields. Amongst the models, the yield reduction of the three cropping systems in 2050 and 2080 would be more by projections from CSIRO model followed by CCCMA and HadCM3 corresponding to the magnitude of increase in temperature in these models (Table 1). Yield reduction would be more for $\mathrm{B} 2$ scenario than $\mathrm{A} 2$ in 2020 and trends would reverse in 2050 and 2080. Equivalent wheat yield reduction in $\mathrm{M}-\mathrm{W}, \mathrm{R}-\mathrm{W}$ and $\mathrm{C}-\mathrm{W}$ cropping systems would be $0.1,3.8$ and $10.2 \%$ in $2020,4.2,8.0$ and 21.0 in 2050 and $13.4,17.0$ and $32.3 \%$ in 2080 , respectively

\section{Adaptation to climate change effects}

A number of methods such as reducing soil temperature and conserving soil water by straw mulching (Jalota et al., 2007), synchronizing plant growth period with favorable weather (Vashisht et al., 2013; Jalota et al., 2011), managing N, P, K and zinc fertilization (Duponi et al., 2006) and creating heat tolerance in plants (Farooq et al., 2011) have been advocated to tone down the impact of climate change. Out of these, synchronization of plant growth period with favorable environmental conditions seems to be most promising as it involves no additional cost. In the present study it was noticed that in 2020,with delaying planting by 7,15 and 21 days yield would be reduced by 2.8 , 7.6 and $13.2 \%$ in maize; $0.4,1.2$ and $2.9 \%$ in rice and $20.2,5.8$ and $-4.8 \%$ in cotton, respectively. The corresponding values in 2080 would be $16.4,20.7$ and 26.2 in maize; $9.2,8.8$ and $10.1 \%$ in rice and $61.9,51.5$ and 42.6 in cotton (Table 4 ). It implies that like the normal planting date, delaying planting date in future would also reduce yield, but the reduction would be least delaying maize by 7 days, rice by $7-15$ days and cotton by 21 days. The magnitude of reduction would be less in rice than maize than cotton. In wheat the yield reduction would be less by delaying planting by 7 days subsequent to maize, by 7-15 days subsequent to rice and by 7 days subsequent to cotton. 


\section{CONCLUSION}

The averaged projections of climate data from three general circulation models ((HadCM3, CCCMA-CGCM2 and CSIROMK2) for two scenarios (A2 and B2) suggest that in future maximum and minimum temperatures would be elevated, which may reduce crop yields by shortening of crop duration. Cotton would be more vulnerable than maize than rice. The wheat vulnerability would depend upon the preceding crop e.g. more subsequent maize than cotton than rice. The reduction in crop yields could be minimized by shifting trans-/planting date in such a way that the plant growth period synchronizes the favorable weather conditions.

\section{REFERENCES}

Bern climate change model (www.ipcc-data.org/ancillary/tarbern.txi).

Buttar, G.S., Jalota, S.K., Sood, A., and Bhushan, B. (2012). Yield and water productivity of Bt cotton (Gossupium hirsutum) as influenced by temperature under semi-arid conditions of north-western India: field and simulation study. Ind. J. Agric. Sci., 82(1):44-49.

Duponi, F.M., Hurkman, W.J., Vensel, W.H., Tanaka, C., Kothari, K.M., Chung, O.K., and Altenbach, S.B. (2006). Protein accumulation and composition in wheat grains: Effects of mineral nutrients and high temperature. Eur. J. Agron., 25:96-107.

Farooq, M., Bramley, H., Palta, J.R., and Siddique, K.H.M. (2011). Heat stress in wheat during reproductive and grain-filling phases. Critical Rev. Plant Sci., 30:1-17.

Haris, A.P., Chhabra, V., and Biswas, S. (2011). Modeling the Impact of anticipated change on wheat yields in different agro-climatic zones of eastern India. J. Agrometeorol., 13:116-18.

IPCC. Summary for policymakers. In: Climate Change (2014): Impacts, Adaptation, and Vulnerability. Part A: Global and Sectoral Aspects. Contribution of Working Group II to the Fifth Assessment Report of the Intergovernmental Panel on Climate Change ((Eds. C.B. Field, V.R. Barros, D.J. Dokken, K.J. Mach, M.D. Mastrandrea, T.E. Bilir, M. Chatterjee, K.L. Ebi, Y.O. Estrada, R.C. Genova, B. Girma, E.S. Kissel,A.N. Levy, S. MacCracken, P.R. Mastrandrea, and L.L. White). pp. 1-32. (Cambridge University Press, Cambridge, United Kingdom and New York, NY, USA).
IPCC-TGICA. (2007). General Guidelines on the Use of Scenario Data for Climate Impact and Adaptation Assessment. Version-2'.pp. 66. Prepared by T.R. Carter on behalf of the Intergovernmental Panel on Climate Change, Task Group on Data and Scenario Support for Impact and Climate Assessment.

Jalota, S.K., Sukhwinder-Singh, Chahal, G.B.S., Ray, S.S., Panigrahy, S., Bhupinder-Singh, and Singh, K.B. (2010). Soil texture, climate and management effects on plant growth, grain yield and water use by rained maize (Zea mays L.)-wheat (Triticumaestivum L.) cropping system: field and simulation study. Agric. Water Manage., 97: 83-90.

Jalota, S.K., Kaur, H., Ray, S.S., Tripathy, R., Vashisht, B.B., and Bal, S.K.(2012). Mitigating future climate change effects by shifting planting dates of crops in Rice-wheat cropping system. Reg. Environ. Change 12(4): 913-922.

Jalota, S.K., Kaur, H., Kaur, S., and Vashisht, B.B. (2013a). Impact of climate change scenario on yield, water and nitrogen -balance and -use efficiency of rice-wheat cropping system. Agric. Water Manage., 116: 29-38.

Jalota, S.K., Kaur, H., Ray, S.S., Tripathy, R., Vashisht, B.B., and Bal, S.K. (2013b). Past and general circulation model driven future trends of climate change in central Indian Punjab: ensuing yield of rice-wheat cropping system. Curr. Sci., 104:105-110.

Jalota, S.K., Khera, R., Arora, V.K., and Beri, V. (2007). Benefits of straw mulching in crop production. J. Res. PAU., 44: 104-17.

Jalota, S.K., Vashisht, B.B., Kaur, H., Arora, V.K., Vashist, K.K., and Deol, K.S. (2011). Water and nitrogen balance, -use efficiency in rice (Oryza sativa L.) - wheat (Triticumaestivum L.) cropping system as influenced by management interventions: Field and simulation study. Exp. Agric., 47(4):609-628.

Jalota, S.K., Vashisht, B.B., Kaur, H., Kaur, S., and Kaur,P. (2014). Location specific climate change scenario and its impact on rice and wheat in Central Indian Punjab. Agric. Syst., 41:77-86.

Kaur, H., Jalota, S.K., Kanwar, R., and Vashisht, B.B. (2012). Climate change impacts on yield, evapotranspiration and nitrogen uptake in irrigated maize (Zea mays)wheat(Triticum aestivum) cropping system: a simulation analysis. Indian J. Agric. Res., 82(3):213-219. 
Kimball, B.A., Kubayashi, K., and Bindi, N. 2002. Response of agricultural crops to free $\mathrm{CO}_{2}$ enrichment. Adv. Agron., 77:293-368.

Package of Practices for Crops in Punjab. 2014. http:// web.pau.edu/content/pf/pp.

Peng, S., Huang, J., John, E.S., Rebecca, C.L., Romeo, M.V., Xuhua, Z., Grace, S.C, Khush, G.S., and Kenneth, G.C. (2004). Riceyields decline with higher night temperature from global warming. 2004. www.pnas.org cgi doi 10.1073 pnas.0403720101 (last accessed on 4.09.14).

Sankaranaryanan, K., Praharaj, C.S., Nalayani, P., Bandyopadhyay, K.K., and Gopalakrishanan, N. (2010). Climate change and its effect on cotton (Gosssypium sp.). Ind. J. Agric. Sci., 80: 561-575.
Statistical Abstract Punjab (2012). http://pbplanning.gov.in/ pdf/Statistical Abstract 2012. pdf (consulted on 0409 2014).

Stockle, C.O., Martin, S.A., and Campbell, G.S. (1994). CropSyst a cropping system simulation model: Water/N budgets and crop yield. Agric. Syst., 46: 335-359.

Tubiello, F.N., Donatelli, M., Rosenzweig, C., and Stockle, C.O. (2000). Effects of climate change and elevated $\mathrm{CO}_{2}$ on cropping systems: model predictions at two Italian locations. Eur. J. Agron., 13: 179-189.

Vashisht, B.B., Mulla, D.J., Jalota, S.K., Kaur, S., Kaur,H., and Singh, S. (2013). Productivity of rainfed wheat as affected by climate change scenario in northeastern Punjab, India. Reg. Environ. Change, 13: 989-998. 